\title{
B. Ergometry and Muscle Physiology
}

\section{BLOOD FLOW AND METABOLISM IN ISOLATEDLY TRAINED FOREARM DURING REST AND EXERCISE}

\author{
K. CAESAR, M.D.* D. JESCHKE, M.D. \& H. F. v. OLDERSHAUSEN, M.D. \\ Medizinische Universitats-Klinik, 74 Tubingen, Germany \\ *Present address: Lehrstuhl II, Innere Medizin, Med. Klinik Köłn-Merheim, \\ Ostiverheimstrasse 200, 5 Köln 91
}

\begin{abstract}
Interval training of the flexor and extensor muscles of the right forearm was conducted with 11 young, healthy persons. Before the beginning, after 6 weeks and after 12 weeks of training, measurements were made at rest and immediately after a standardised exercise in supine position. Simultaneously venous and arterial blood were taken from the trained forearm, and lactate, pyruvate and $\mathrm{pO}_{2}$ were determined. The blood flow was registered with a segment plethysmograph.

After training, the blood flow at rest and immediately after standardised exercise is not significantly changed. The venous lactate concentration of the trained forearm and the arterio-venous difference of lactate increases more with the same work load after 6 and 12 weeks of training than before. The pyruvate concentration increases less after muscle work. The lactate pyruvate quotient in venous blood of the exercising forearm increases with progress of the isolated training. The venous oxygen pressure is not altered compared to the values before training. The arterio-venous difference of the oxygen pressure declines less after training exercise.
\end{abstract}

The metabolic changes are explained by improved glycolytic performance of the trained muscle cell. The improved glycolysis probably precedes the alteration of the blood flow in this kind of short interval-training of isolated muscle groups.

Eine Verbesserung des Trainingszustandes äußert sich in charakteristischen zirkulatorischen und metabolischen Umstellungen, wie aus zahlreichen Befunden bekannt ist (Übersichten bei 5, 12, 14, 16). Bei Untersuchungen nach einer allgemeinen körperlichen Belastung und bei Versuchspersonen im trainierten Zustand können Trainingsveränderungen in der Kreislaufperipherie und im Stoffwechsel der trainierten Muskulatur von einer veränderten Leistungsfähigkeit besonders des kardio-pulmonalen Systems und der Stoffwechselfunktionen beeinflußt werden.

Um die peripheren Anpassungsvorgänge an die geforderte Leistungssteigerung für sich allein zu erfassen, wurde ein Training nur der Streck- und Beugemuskulatur des rechten Unterarmes vorgenommen. 11 gesunde jugendliche Versuchspersonen mußten dazu ein Gewicht von $2 \mathrm{~kg}$ an den Fingern täglich während einer Übung 60 mal in 2-Sekunden-Abständen durch Streckung und Beugung im Handgelenk anheben. Die standardisierten Belastungsversuche wurden ebenfalls auf den trainierten Unterarm beschränkt und bestanden in 60 Kontraktionen der Fingerbeuger, wie sie in gleicher Form während des täglichen Trainings durchgeführt wurden.
Die Untersuchungen erfolgten vor Beginn und nach 6 und 12 Wochen Training. In Ruhelage, sofort und 3 Minuten nach dem Belastungsversuch wurden Laktat, Pyruvat und Sauerstoffdruck im Blut bestimmt, das einer tiefen Vene des trainierten Unterarmes und der Arteria femoralis mit Verweilkanülen entnommen wurde. Die Unterarmdurchblutung wurde mit einem Manschettenplethysmographen (1) zu den gleichen Zeitpunkten gemessen.

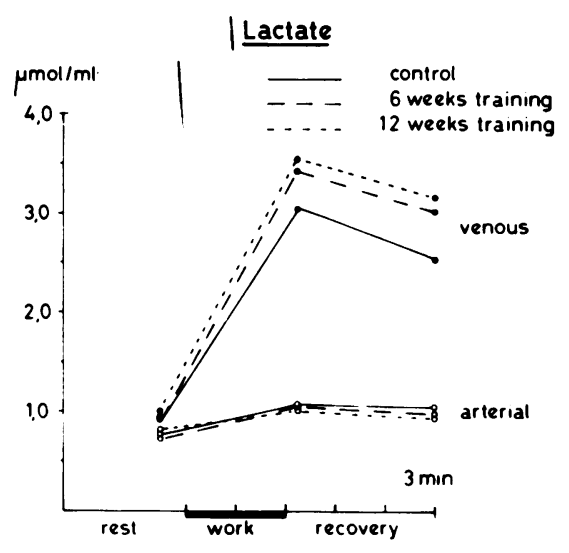


Wie Abb. 1 zeigt, ist die Laktatkonzentration im venösen Blut sofort nach der gewählten Arbeitsbelastung signifikant $(P=\langle 0,01)$ gegenüber dem Ruhewert erhöht. Die Ergebnisse stimmen mit denen von Pernow und Wahren $(15,17)$ bei vergleichbarer Belastung am Handergometer überein. 3 Minuten nach Belastung ist der venöse Laktatspiegel schon wieder abgefallen, entgegen den Befunden nach längerer Arbeit größerer Muskelgruppen $(10,12)$, liegt jedoch mit $2,5 \mathrm{nmol} / \mathrm{m}$ noch signigikant über dem Ruhewert.

Dieser Anstieg der brachial-venösen Laktatkonzentration nach Muskelarbeit ist nach 6 und 12 Wochen Unterarmtraining signifikant $(P=<0.01)$ stärker als vor Trainingsbeginn. Und in der Erholungsphase gibt die trainierte Muskulatur mehr Laktat ab im Vergleich zu den Werten vor Training.

Die arterielle Laktatkonzentration steigt im Mittel nach der kurzfristigen Belastung nur gering an und zeigt unter Unterarmtraining kein verändertes Verhalten (Abb. 1). Nach 6 und 12 Wochen Training ist daher die venös-arterielle Laktatdifferenz nach der gewählten Muskelarbeit größer als vor dem Training.

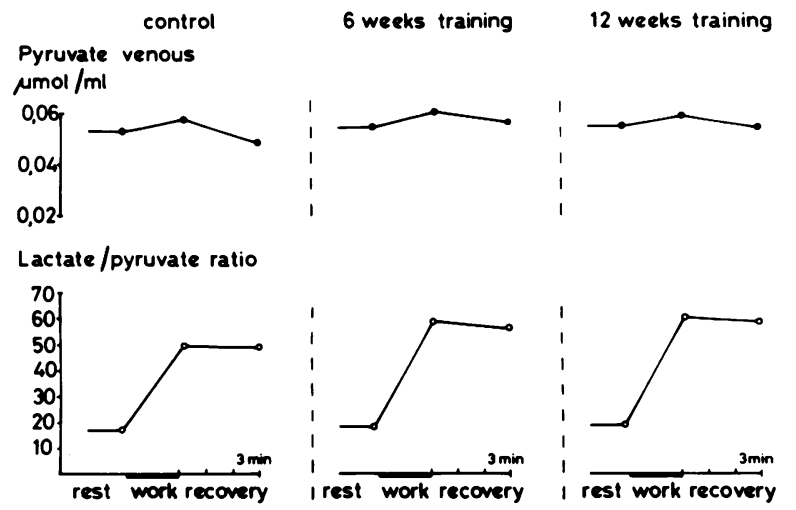

Der venöse Pyruvatspiegel ist nach Arbeit der Unterarmmuskulatur nur wenig erhöht und fällt nach 3 Minuten Erholung wieder in den Bereich der Ruhewerte zurück (Abb. 2). Das isolierte Unterarmtraining äußert sich in einer etwas verminderten Abgabe von Pyruvat in das venöse Blut nach Muskelarbeit, wie das auch aus Untersuchungen an trainierten Sportlern bekannt ist (12, 13).

In dem deutlich vergrößerten Laktat-PyruvatQuotienten tritt das unterschiedliche Verhältnis in der Abgabe von Laktat und Pyruvat aus der Muskelzelle besonders hervor (Abb. 2). Während des Unterarmtrainings wird der Laktat-Pyruvat-Quotient nach Belastung weiter vergrößert, als Ausdruck der zunehmend erhöhten Laktatkonzentration und der niedrigeren Pyruvatwerte. 
erhöhte Laktatabgabe nach Training einzelner Muskelgruppen nicht mit einem Sauerstoffmangel in Zusammenhang.

Wir nehmen an, daß die erhöhte Laktatabgabe nach dem Training nur eines Unterarmes mit kurzfristigen starken Belastungen der Ausdruck für die im Training erworbene Fähigkeit der Muskulatur zu einer verbesserten glykolytischen Energiegewinnung ist. Vom Intervalltraining mit kurzen Belastungsphasen sind hohe Laktatspiegel bekannt, und es ist dabei eine Steigerung der Glykolyse im Muskel anzunehmen (9).

Unsere Ergebnisse stehen im Gegensatz zu Befunden an Sportlern, bei denen wiederholt eine geringere Laktatkonzentration nach Belastung als bei Normalpersonnen gemessen wurde $(2,6,8,12,13)$. Bei unseren Untersuchungen entfällt wahrscheinlich die bei Trainierten bekannte vermehrte Laktatoxydation durch den Herzmuskel, ruhenden Skeletmuskel und andere Organe wie vor allem die Leber (7), da bei dem Training nur einzelner Muskelgruppen die Trainingsauswirkungen weitgehend auf die geübte Muskulatur beschränkt b!eiben. Hierin kann neben der Wirkung auf die glykolytische Energiegewinnung eine weitere Ursache für die von uns gefundene erhöhte venöse Laktatkonzentration nach Muskelarbeit bei isoliertem Muskeltraining gesehen werden.

Mit Unterstützung durch das Zentralkomitee für die Forschu auf dem Gebiete des Sports e.V. im Deutschen Sportbund

\section{LITERATUR}

1. BARBEY, K., P. BARBEY: Ein neuer Plethysmograph zur Messung der Extremitätendurchblutung. $Z$. Kreislaufforsch. 52, 1129 (1963).

2. BORGARD, W., G. MATTHIESSEN, G. ZAEPER: Einwirkungen des Trainings auf Atmung und Kreislauf. Klin. Wschr. 16, 385 (1937).

3. CAESAR, K., M. NEHER, P. SCHOLLMEYER, E. STEIN: Veränderungen der Ruhedurchblutung, der reaktiven Hyperämie und der Durchblutung nach Belastung in der Unterarmmuskulatur im Verlauf eines isometrischen Trainings. Z. Kreisl.-Forsch. 58, 345 (1969).

4. CAESAR, K., D. JESCHKE: Trainingseinflüsse auf die Kreislaufperipherie. Internist 11, 283 (1970).

5. HOLLMANN, W.: Körperliches Training als Prävention von Herz-Kreislaufkrankheiten. Stuttgart 1965.

6. HOLMGREN, A., G. STRÖM: Blood lactate concentration in relation to absolute and relative work load in normal men, and in mitral stenosis, atriel septal defect and vasoregulatory asthenia. Acta med. scand. 3, 163 (1959).

7. KEUL, J., E. DOLL, H. STEIM, H. HOMBURGER, H. KERN, H. REINDELL: Über den Stoffwechsel des menschlichen Herzens. Pflagers Arch. ges. Physiol. 282, 1 (1965).

8. KEUL, J., E. DOLL, D. KEPPLER, H. REINDELL: Die Veränderungen arterieller Substratspiegel unter dem Einfluß körperlicher Arbeit. Int. Z. angew. Physiol. Arbeitsphysiol. 22, 356 (1966).

9. KEUL, J., E. DOLL, D. KEPPLER, H. REINDELL: Intervalltraining und anaerobe Energiebereitstellung. Sportarzt and Sportmed. 18495 (1967)

10. KEUL, J., E. DOLL, D. KEPPLER: The Substrate Supply of the Human Skeletal Muscle at Rest, during and after Work. Experintia 23, 974 (1967).

11. KEUL, J., D. KEPPLER, E. DOLL: Der Lactat-Pyruvat-Quotient und seine Beziehung zum Sauerstoffdruck im arteriellen, femoralvenösen und coronarvenösen Blut. Sportarzt u. Sportmed. 19, 435 (1968).

12. KEUL, J., E. DOLL, D. KEPPLER: Muskelstoffwechsel. Barth, München 1969.

13. KÜMPER, W., R. JUCHEMS: Das Verhalten von Pyruvat und Laktat unter ergometrischer Belastung bei Sportlern, Normalpersonen und Patienten mit funktionellen Herz- Kreislaufstörungen. Sportarzt u. Sportmed. 9, 357 (1969).

14. MELLEROWICZ, $H_{.}$: Über das Ökonomieprinzip in Arbeit und Leistung des trainierten Kreislaufs. Arch. Kreisl.-Forsch. 24, 70 (1956). 
15. PERNOW, B., J. WAHREN: Lactate and pyruvate formation and oxygen utilisation in the human forearm muscles during work of high intensity and varying duration. Acta physiol. scand. 56, 267 (1962).

16. REINDELL, H., H. KLEPZIG, H. STEIM, K. MUSSHOFF, H. ROSKAMM, E. SCHILDGE: Herz-Kreislaufkrankheiten und Sport. Barth, München 1960.

17. WAHREN, J.: Quantitative Aspects of Blood Flow and Oxygen Uptake in the Human Forearm during Rhythmic Exercise. Acta physiol. scand. Vol. 67, Suppl. 269 (1966).

\title{
EVALUATION OF PHYSICAL WORK CAPACITY IN NORWEGIAN FEMALE GYMNASTS
}

\author{
S. OSEID \& L. HERMANSEN \\ Paediatric Research Institute, University Hospital, Rikshospitalet, Oslo, \\ and Institute of Work Physiology, Oslo, Norway
}

\begin{abstract}
12 top female gymnasts, mean age 15 years, 8 months ( 14 years -19 years) were studied. They were characterised by small height (mean $159 \mathrm{~cm}$ ) and low weight (mean $48.9 \mathrm{~kg}$.). They had frequent injuries, mainly to the joints and the back. $50 \%$ had decreased flexibility of the lower back and increased lordosis which reduced their performance.

Estimations of maximal oxygen uptake, muscle strength, fat free body weight and skeletal diameters have been correlated to the individual performance level. The same parameters have also been correlated to results obtained in 30 girls of the same age groups but not participating in competitive sport.
\end{abstract}

The studies revealed no difference in maximal oxygen uptake between the two groups, while the gymnasts exhibited a considerably greater muscle strength, particularly in the triceps and the abdominal muscles. The radio-ulnar diameters were significantly greater in the gymnasts, while the bicondylar femur diameters were not significantly different. Measurements of 11 different skinfolds revealed a mean of $9.0 \mathrm{~mm}$. in the gymnasts, $15.6 \mathrm{~mm}$. in the control group, indicating a much lower fat free body weight in the gymnasts. There was a fairly good correlation between the maximal oxygen uptake levels, the muscle strength and the individual level of performance.

\section{COMPARISON OF THE BICYCLE ERGOMETER TEST AND THE WORKING CAPACITY OF RUNNERS}

\author{
J. FRIC, M.D. and H. MELLEROWICZ, M.D. \\ Hradec Kralove 1, Svendova 1041, Czechoslovakia
}

\begin{abstract}
In the training of middle distance runners the rate of continuous load has increased distinctly during the last years. Maximal oxygen consumption in contemporary champion runners for middle and long distances did not differ significantly in our groups of athletes. The other values indicating adaptation of the circulatory system were similar in both groups. Only the ratio of the cardiac volume per $\mathrm{kg}$ of body weight is higher in marathon runners than in runners for middle distances $(p<0.001)$. Statistically significant differences were found in the values of the respiratory coefficient $(R)$, as well in the last minute as in the rapidity of the increase during the work. According to Issekutz the excessive $\mathrm{CO}_{2}$ which forms the so called "nonmetabolic" $\mathrm{R}$ correlates rather to the rate of anaerobic metabolism than to the lactate concentration.

This observation provides evidence of the usefulness of continual registration of $R$ in the bicycle ergometer test. From the rapidity of the increase of $R$ and from the total level of oxygen consumption the estimation of aerobic and anaerobic capacity, which is decisive for the performance for middle distances, can be made.
\end{abstract}




\title{
EXERCISE AND THE INCIDENCE OF MUSCLE FIBRE SPLITTING ${ }^{1}$ \\ ${ }^{1}$ Supported by U.S.P.H.S. Grant HD 03918
}

\author{
R. E. CARROW ${ }^{2}$, W. W. HEUSNER ${ }^{3}$ and W. D. VAN HUSS 4 \\ ${ }^{2}$ Department of Anatomy, Michigan State University, East Lansing, Michigan, USA \\ ${ }^{3 / 4}$ Department of Physical Education, Michigan State University, East Lansing, Michigan, USA
}

\begin{abstract}
Fifty-six rats were divided into seven groups. Control (C) animals were confined to sedentary cages. Voluntary (V) animals were housed in similar cages equipped with revolving drums permitting each rat to exercise at will. Short endurance (SE), medium endurance (ME), and long endurance (LE) groups housed in sedentary cages were forced to run for short, medium and long periods of time under heavy, moderate and low work loads respectively. An electrical stimulation control (ES) was matched with the SE group to control for the effects of the stimuli used in the training programmes. Swimmers (S) housed in sedentary cages were subjected to a long duration, low-intensity swimming programme.

The rats were exercised five days per week for eight weeks. At sacrifice, the soleus, plantaris and gastrocnemius muscles were removed and frozen. Serial sections were treated with a variety of histochemical procedures. Total muscle fibre counts of the soleus muscles of $C, V, E S$, and $S$ groups averaged 1,876, 1,962, 1,741 and 1,898 fibres respectively. All three running groups averaged over two thousand fibres per muscle. Extensive fibre splitting was found in the running groups and accounts for the decreased fibre sizes in these animals. Capillary to fibre ratios also shifted and were commensurate with muscle fibre sizes.
\end{abstract}

\section{Introduction}

The means by which skeletal muscles increase in size has been a point of contention for nearly a century. Gudz ('64) saw pathology in the muscles of dogs overtrained by running. Edgerton ('70) noted evidence of fibre splitting in rats forced to swim and Van Linge ('62) and Reitsma ('69) made similar observations on surgically overloaded muscles of rats. The surgical approach by Denny-Brown ('67) and the physical exercise methods of Hettinger and Muller ('53) and Morpurgo (1897) provided no evidence of a numerical increase in muscle fibres.

At the present time physiologic hypertrophy supports the volumetric rather than the numerical hypothesis. Recent studies by Carrow et al. ('67), and Edgerton et al. ('69), along with the information presented here with regard to specific training effects upon skeletal muscle indicate that a fresh look at this thesis is in order.

With this objective in mind fifty-six adult male white rats were assigned randomly (eight per group) to the following categories for a period of eight weeks.

I. Control Group (C): housed in sedentary cages throughout the experiment.

II. Voluntary-exercise (V): housed in standard cages with exercise wheel attached so rats could exercise at will.
III. Short-duration Running Group (S): subjected to a short-duration, high-intensity programme.

IV. Medium-duration Running Group (M): subjected to a medium-duration, moderate-intensity programme.

V. Long-duration Running Group (L): subjected to a long-duration, low-intensity programme.

VI. Stimulus-control Group (E): subjected to same stimulus conditions as $S, M$, and $L$ but will not run in exercise wheel.

VII. Long-duration Swimming Group (W): subjected to. long-duration, low-intensity programme of continuous swimming with tails weighted.

NOTE:

1. All animals except those in $V$ were housed in sedentary cages.

2. Groups $S, M$ and $L$ were exercised in stimulus controlled wheels.

Prior to sacrifice all animals were anesthetized and subsequently injected with Pelikan ink. The animals remained alive for ten minutes and the ink was circulated by the pumping action of the heart. At the time of death the right gastrocnemius, soleus and plantaris muscles were excised as a unit. The muscle unit was quick-frozen in isopentane previously cooled with liquid nitrogen. The belly of each muscle was mounted 
with $5 \%$ gum tragacanth. Serial sections ten microns thick were cut in a cryostat at $-200 \mathrm{C}$.

Immediately after sectioning, the tissues were placed on cover slips and dried. Alternate sections were stained with hematoxylin and eosin, (H \& E) and the periodic acid-Schiff (PAS) method (McManus '46). Total, normal and fractionated fibre counts were made from projected $H$ \& $E$ sections. Fibres from each muscle were traced and subsequently measured using a compensating polar planimeter. Capillary to fibre ratios were determined from sections stained with PAS.

A control data 3600 computer was used to analyze data using one-way analyses of variance. When the F-ratio was significant, the Duncan multiple range test was used to determine which means differed. The .05 level of probability was chosen to determine significance.

Evidence of muscle fibre splitting was, easily detected in both longitudinal and cross sections of short, medium and long-endurance groups (Figs. 1, 2).

Tane 1

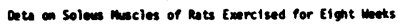

\begin{tabular}{|c|c|c|c|c|c|}
\hline Ireatuent & $\begin{array}{l}\text { cody } \\
\text { Wt.-. } \\
\text { tis. }\end{array}$ & $\begin{array}{l}\text { Copillaries } \\
\text { Por fitoer }\end{array}$ & $\operatorname{man}_{\text {Fiber sizes }}\left(u^{2}\right)$ & $\begin{array}{l}\text { men counts } \\
\text { of all Fibers }\end{array}$ & $\begin{array}{l}3 \text { Fibers } \\
\text { Frectionated }\end{array}$ \\
\hline Control & 473 & 6.6 & 4.931 & 1,876 & 0.6 \\
\hline volentary & 436* & 600 & 5,209 & 1,962 & 1.3 \\
\hline $\begin{array}{l}\text { Shert } \\
\text { Eneverence }\end{array}$ & 429* & 6.0 & 4,511 & 2,079 & 3.8* \\
\hline Encurencen & $424^{\circ}$ & 6.8 & 4,966 & 2,247 & $3.5 \%$ \\
\hline Leng & 405* & 6.0 & 4,326 & $2,370_{\text {;ै. }}^{*}$. & 2.4 \\
\hline $\begin{array}{l}\text { Electrical } \\
\text { seiviation } \\
\text { control }\end{array}$ & 452 & 5.9 & 5.143 & $1,741 *$ & 2.6 \\
\hline switu & 447 & 7.1 & 5,601 & $1,899^{\circ 0 *}$ & 1.100 \\
\hline
\end{tabular}

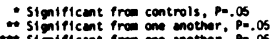

Actual fibre counts in the running groups showed an increase in the numbers of fibres per muscle when compared with the controls. However, only the difference attributed to $\mathrm{L}$ group was statistically significant. Fibre counts in the swimmers were nearly identical to those of the controls. While the fibre counts were greater in the $L$ than any other group, the greatest percentage of split fibres was found in the $S$ and $M$ groups. No statistically significant differences were found in the muscle fibre sizes or capillary to fibre ratios. Analyses of the body weight data showed that each of the running groups (but not swimmers) were significantly lighter than the controls.

In Figure 2, three separate fibres have been noted as $A, B$ and $C$. When these fibres were traced through 135

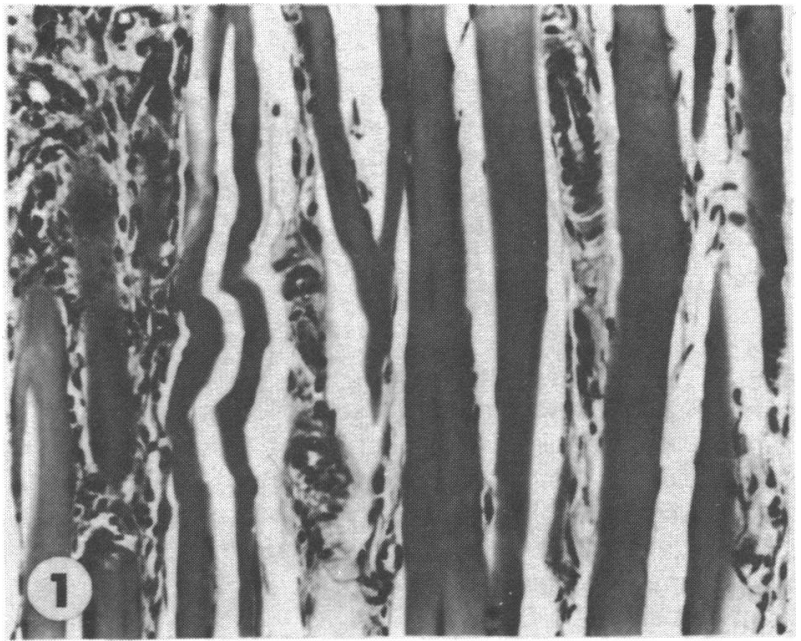

Fig. 1. Longitudinal section of soleus muscle, Medium endurance group. Chain of centrally placed nuclei is evident in one fibre. Longitudinal splitting is prominent at three separate locations. H. \& E. $\times 210$.

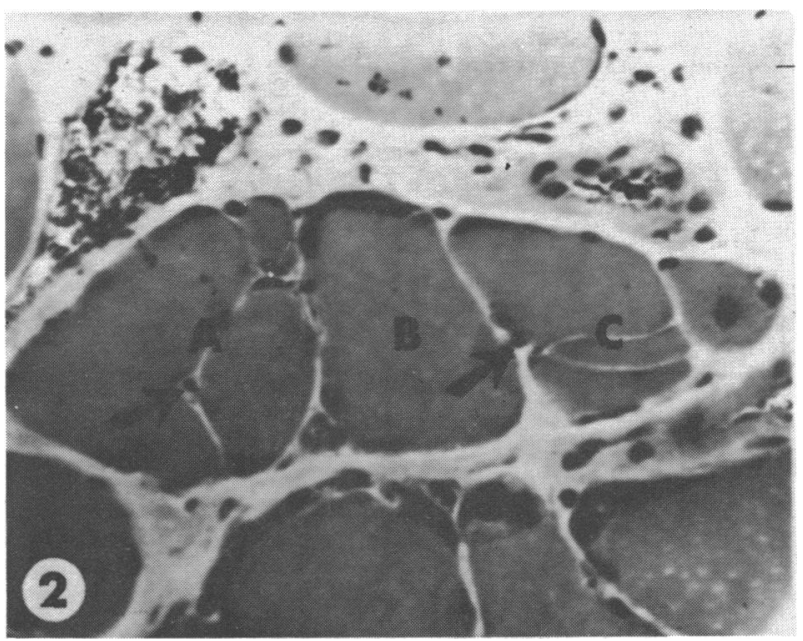

Fig. 2. Cross section from same muscle as shown in figure one. Serial sections show that three fibres are representated here: (A) has split into three parts, $(B)$ is intact and $(C)$ has split into four separate "subfibres". Note the ink filled capillaries between the small fibres (Arrows). H. \& E. X 500 .

serial sections it was found that the three subfibres of $A$ became one. The four "subfibres" of C followed the same pattern while $B$ remained intact the entire distance. The numerical differences noted are appreciated more fully when the splitting process is viewed in longitudinal section (Fig. 2).

In any experiment involving physical exercise it is of fundamental importance to know whether or not the exercise programme is sufficient to create the desired effect. In the present study the loss of weight by animals 
in the exercised groups is indicative of a positive exercise routine. A more important clue to the degree of physical exertion is the central migration of nuclei and an increase in the number of myofibrils (Denny-Brown '60). The central migration of nuclei was one of the outstanding features in muscles of animals from our $\mathrm{S}$, $M, L$ and $W$ groups. Although myofibrillar counts are not yet completed, all indications point to an overall increase in number.

The arrangements of the capillaries between the fractionated fibres is reminiscent of those described by Reitsma ('69). The workload imposed by his surgically induced approach was certainly greater than that created in this experiment. Nevertheless, circulatory adjustments of a similar nature are apparent in both studies. Whether or not these alterations indicate a growth of new vessels is not known, but, studies are presently underway to evaluate this parameter.
This study is an integral part of a much larger project pertaining to the effects of physical exercise upon skeletal muscle. Our review of the literature indicates it to be the first project where total and differential muscle fibre counts and measurements have been made to gain insight into the volumetric versus numerical basis of physiological hypertrophy. Reference to muscle fibre splitting as "pathology" may be justified in some instances but an unfair assessment in others. The status of our present knowledge leads us to believe that under certain conditions it may represent a beneficial adaptation of muscle to physical exercise.

\section{Acknowledgements}

Deep thanks is expressed to Barbara Wheaton and Patricia Lamb for their technical work on this project.

\section{REFERENCES}

1. ADAMS, R. E., L. M. EATON and G. M. SHY. Neuromuscular Disorders. Williams and Wilkins Co., Baltimore, 1960.

2. CARROW, R. E., R. E. BROWN and W. D. VAN HUSS. Fibre sizes and capillary to fibre ratios in skeletal muscle of exercised rats. Anat. Rec. 159: 33-59, 1967.

3. DENNY-BROWN, D. Experimental hypertrophy, regeneration and degeneration. In: Adams, R. D., L. M. Eaton and G. M. Shy. Neuromuscular Disorders. Williams and Wilkins Co., Baltimore, 1960, pp. 146-196.

4. DENNY-BROWN, D. Innervation and blood vessels. In: Adams, R. D., D. Denny-Brown and C. M. Pearson. Diseases of Muscle. Paul B. Hoeber, Inc. New York, 1962, pp. 62-131.

5. EDGERTON, V. R., L. GERCHMAN and R. E. CARROW. Histochemical changes in rat skeletal muscle after exercise. Exp. Neurol. 24: 110-123, 1969.

6. EDGERTON, V. R. Morphology and histochemistry of the soleus muscle from normal and exercised rats. Am. J. Anat. 127: 81-88, 1970.

7. GUDZ, P. L. Morphological changes in extremity muscles and nerves under conditions of overtraining. Arkh. Anat. 45: 55, 1963; Excerpta Med. sect. XIX 7: 463, 1964.

8. HETTINGER, T. and E. A. MULLER. Muskelleistung and Muskel-training. Arbeitsphysiologie 15: 111-126, 1953.

9. McMANUS, J. F. A. Histological demonstration of mucin after periodic acid, Nature, 158: 202, 1946.

10. MORPURGO, B. Ueber Activitats - Hypertrophie der willkurlichen Muskelm. Virchow Arch Path Anat 150: 522-554, 1897.

11. REITSMA, W. Skeletal muscle hypertrophy after heavy exercise in rats with surgically reduced muscle function. Aim. J. Phys. Med. 48 (5) 237-258, 1969.

12. VAN LINGE, B. The response of muscle to strenous exercise. J. Bone Joint Surgery. 44B: 711-721, 1962. 


\title{
EFFECT OF ECCENTRIC AND CONCENTRIC MUSCLE CONDITIONING ON TENSION AND ELECTRICAL ACTIVITY OF THE BICEPS MUSCLE
}

\author{
P. V. KOMI, Ph.D.* and E. R. BUSKIRK, Ph.D. \\ Laboratory for Human Performance Research, \\ The Pennsylvania State University, U.S.A. \\ *Present address: Kinesiology Laboratory, University of Jyvaskyla, Jyvaskyla, Finland
}

\begin{abstract}
A study was undertaken to compare the conditioning effects on muscle tension and electrical activity (EMG) of repeated maximal eccentric and concentric contractions of the right forearm flexors ( $m$. biceps primarily). A special electrical dynamometer was used permitting a constant rate of contraction of the biceps throughout the movement range of 1050. The subjects were 31 young college men students, 10 of which served as controls. The experimental subjects went through a seven week muscle conditioning programme, in which they exerted six daily either maximum eccentric $(n=11)$ or concentric $(n=10)$ contractions four times a week.

The results on various measurements showed that eccentric conditioning increased isometric, eccentric and concentric tension $(p<0.01)$. Concentric conditioning increased only eccentric $(p<0.05)$ and concentric $(p<0.01)$ tension. On the average eccentric conditioning increased muscle tension more than concentric conditioning. During early conditioning the eccentric group complained of muscle soreness, which was associated with a concomitant drop in strength during the first week. Neither group produced any significant reduction in maximal integrated EMG with any type of contraction. The mean EMG in both groups increased for the first three weeks and then decreased. In the eccentric group the "plateau" EMG was retained longer than in the concentric group. In all groups the relationship between EMG and isometric tension was significantly quadratic during pre-conditioning tests. During conditioning the regression lines became more linear although the changes were nonsignificant. The muscle tension was dependent on muscle length, but the EMG stayed constant over the entire movement range. The maximum EMG was same in all types
\end{abstract} of contraction.

\section{EINFLUSS DES EKZENTRISCHEN UND KONZENTRISCHEN MUSKELTRAINING AUF KRAFT UND ELEKTRISCHE AKTIVITÄT DES BICEPS-MUSKELS}

\author{
PAAVO V. KOMI, Ph.D. and E. R. BUSKIRK, Ph.D.
}

\section{ZUSAMMENFASSUNG}

Es wurde eine Untersuchung durchgeführt um die Einflüsse auf Muskelkraft und elektrische Aktivität (EMG) von wiederholten maximalen ekzentrischen und konzentrischen Kontraktionen des menschlichen Unterarmbeugers (hauptsächlich $\mathrm{m}$. Biceps) zu vergleichen. Ein spezialer Elektrodynamometer ermöglichte dass die Geschwindigkeit der Kontraktion des Biceps-Muskels konstant innerhalb der Grenzen 1050 Bewegung blieb. Die Probanden waren 31 Studenten, von denen 10 als Kontrollgruppe dienten. Jeder experimentielle Proband führte ein siebenwöchiges Muskeltrainings-program durch mit entweder maximalen ekzentrischen $(N=11)$ oder konzentrischen $(N=10)$ Kontraktionen des rechten Unterarmbeugers sechsmal täglich und viermal wöchentlich.

Zahlreihe Messungen zeigten, dass das ekzentrische Training einen Zuwachs in isometrischer, ekzentrischer, und konzentrischer Spannung ergab $(p<0.01)$. Das konzentrische Training erhöhte nur ekzentrische $(p<0.05)$ und konzentrische $(p<0.01)$ Spannung. Als Mittelwert verbesserte das ekzentrische Training die Muskelkraft mehr als das konzentrische Training. Im Anfang des Training hatten die Probanden in der ekzentrische Gruppe Muskelschmerz in Zusammenhang mit einer gleichzeitiger Minderung in der Muskelspannung während der ersten Woche des Trainings. Beide Gruppen hatten keinerlei signifikante Verminderung in maximaler intergrierter EMG bei keinem der Kontraktionstypen. Die mittlere EMG nahm in beiden Gruppen während ersten drei Wochen zu und nahm danach ab. In der ekzentrischen Gruppe hielt sich das "Plateau" EMG länger als in der konzentrischen Gruppe. In allen Gruppen waren die Beziehungen zwischen EMG und isometrischer Spannung quadratisch während der Vor-Trainingsteste. Während des Training wurden die Regressionen mehr linear, wenn auch nicht in signifikantem Ausmasse. Die Muskelspannung hing von der Muskellänge ab, aber die EMG blieb konstant innerhalb der Grenzen der Bewegung. Die maximale EMG war dieselbe in allen kontraktionstypen. 


\title{
OBITUARY
}

\section{Professor Michio Ikai}

Just as we go finally to press we are distressed to hear of the sudden death of Michio Ikai in Japan on January 3rd, 1972. He was well known to many exercise physiologists and clinicians in the United Kingdom, the Americas and in many other parts of the world. He was a professor in the School of Education of the University of Tokyo, Director of the Physiology Laboratory of the Physical Education Dept. Before that, he was a graduate student in Physiology in Tokyo University School of Medicine, in which department he left with the rank of assistant professor.

I first met him at the 17th World Congress of Sports Medicine in Mexico, 1968, listened with interest to his communication and enjoyed several informal talks with him. He presented a paper, published in this journal, at the 18th World Congress, and joined our Association at that time. His widow, Mrs. Nobuko Ikai, writes "It was an honour for us that he could join the British Association of Sport and Medicine in 1970". I disagree. It was an honour for us that he joined.

H. E. Robson

\section{TRAINING OF MUSCLE STRENGTH AND POWER IN ATHLETES}

$$
\text { MICHIO IKAI, M.D. }
$$

School of Education, University of Tokyo, Hongo, Bunkyo-Ku, Tokyo, Japan

\begin{abstract}
For better athletic performance, the energy must be fully developed by either isometric or isotonic muscle contractions. The upper limit of energy transformation was demonstrated in case of stimulating electrically the muscle with exertion of $30 \%$ greater strength than the maximal voluntary contraction.

Using ultrasonic photography it was assessed that muscle strength increased by strength training despite insignificant increases in cross-sectional area of muscle until the fourth week. The strength per unit cross-sectional area was developed from 6.3 to $9 \mathrm{~kg} / \mathrm{cm}^{2}$. In practical situations of athletics, dynamic and explosive energy release is required.

In an experiment with 'inertia wheel', sprinter and jumper demonstrated excellent power (= force $X$ speed) showing greater than that expected from the relationship between strength and power for a certain athletic group. Further, in force-velocity relationships tested by an isotonic lever system, the maximal power appeared under the load equivalent to about $35 \%$ of isometric strength in any subjects.

From these observations it may be suggested that muscle training should be carried out so as not only to improve strength but also to produce greater power in respect of force-velocity characteristics for each athletic event.

\section{Introduction}

In every athletic event it must be essential to know how the chemical energy could be transformed into mechanical energy efficiently. It must be a very old theme and had been challenged by many people in laboratories as well as in athletic fields. But there may be some things to be solved in advance with newly acquired

scientific knowledge. Sometimes quite basic, sometimes more practical, sometimes analytical and sometimes integrative. At the Laboratory for Physiologic Research in Physical Education, University of Tokyo, a series of studies on training of muscle strength and power have been conducted for years. Here I would like to present some of the results related to the mechanical performance.
\end{abstract}




\section{The Upper Limit of Muscle Strength}

As had been discussed everywhere for many decades since the study by Angelo Mosso, the upper limit of muscle strength has been rather difficult to be found decidedly at any time practically. This means that the level of activation of the brain, which controls the nervous discharge to the acting muscle, is changed often. Although, it is very difficult to keep the brain activity at the highest level, for a long time, it must be possible to keep it at the highest for a short time by voluntary concentration. The upper limit of muscle strength could be got at this moment. On the same line as studied by $A$. $\mathrm{H}$. Steinhaus and myself, I had conducted an experimental study with $\mathrm{K}$. Yabe on measurement of maximum strength by electrical stimulation and voluntary maximal effort. There were several important studies by the similar procedure of electrical and voluntary stimulation. However there are some discrepancies among the results. But this discrepancy may be caused from different grade of training of the subjects. In intensively trained subjects, the maximum strength could be very close in both cases by electrical as well as by voluntary stimulation, while in ordinary subjects it could not.

K. Yabe and I used an electric stimulation of $50 \mathrm{cps}$. $5 \mathrm{msec}$. and 50 Volts, with the duration of $0.5-1.0$ second on the ulnar nerve from the skin. In 10 subjects, who were ordinary healthy males aged from 19 to 27 , the maximum strength by electric stimulation was found higher significantly in all subjects by $30 \%$ in the average, compared $12.2 \mathrm{~kg} \pm 1.04$ (S.D.) in voluntary, and 15.9 $\mathrm{kg} \pm 0.82$ (S.D.) in electric stimulation. This result confirmed the former study by A. H. Steinhaus and myself in which the maximum level of strength could be elevated by some procedure like hypnotic suggestion by about $30 \%$ than the ordinary condition. This means that we used to keep $30 \%$ of the highest level of strength as "reserve force" for emergency. People need sometimes this emergency force in athletic competition.

\section{Training of Muscle Strength}

Study on muscle has been devoted by many authors with long lasting efforts from practical importance as well as academic one. It has been well known that a good deal of systematic researches by Th. Hettinger, W. Rohmert and A. E. Müller. In this field of training, there are still some difficult problems remaining to be solved by further studies. And also some discrepancies seem to exist among results obtained by several authors. This may be caused by the fact that the maximum strength was not always fully developed to the highest level by ordinary voluntary effort.

From this point of view, T. Fukunaga and I have conducted a series of studies on training effect on strength and cross-sectional area of muscle, as well as the strength per unit cross-sectional area by means of ultrasonic photography. As was presented by the same authors in 1968, the strength per unit cross-sectional area measured by the same method on the flexor of the upper arm was found to be almost the same with the average of $6.3 \mathrm{~kg} / \mathrm{cm}^{2}$ at extended position, and 4.7 $\mathrm{kg} / \mathrm{cm}^{2}$ at flexed position, regardless of age and sex in ordinary healthy persons ranged from 12 to 20 's without special muscle training. This result suggests that there is a linear relationship between the strength and the cross-sectional area of the acting muscle in ordinary population. In this study, however, it was worthy to note that the distribution of the strength per unit cross-sectional area of muscle was ranged from $4 \mathrm{~kg} / \mathrm{cm}^{2}$ to $8 \mathrm{~kg} / \mathrm{cm}^{2}$ with considerable large variation. A question occured how long the individual value of strength per unit area could be constant.

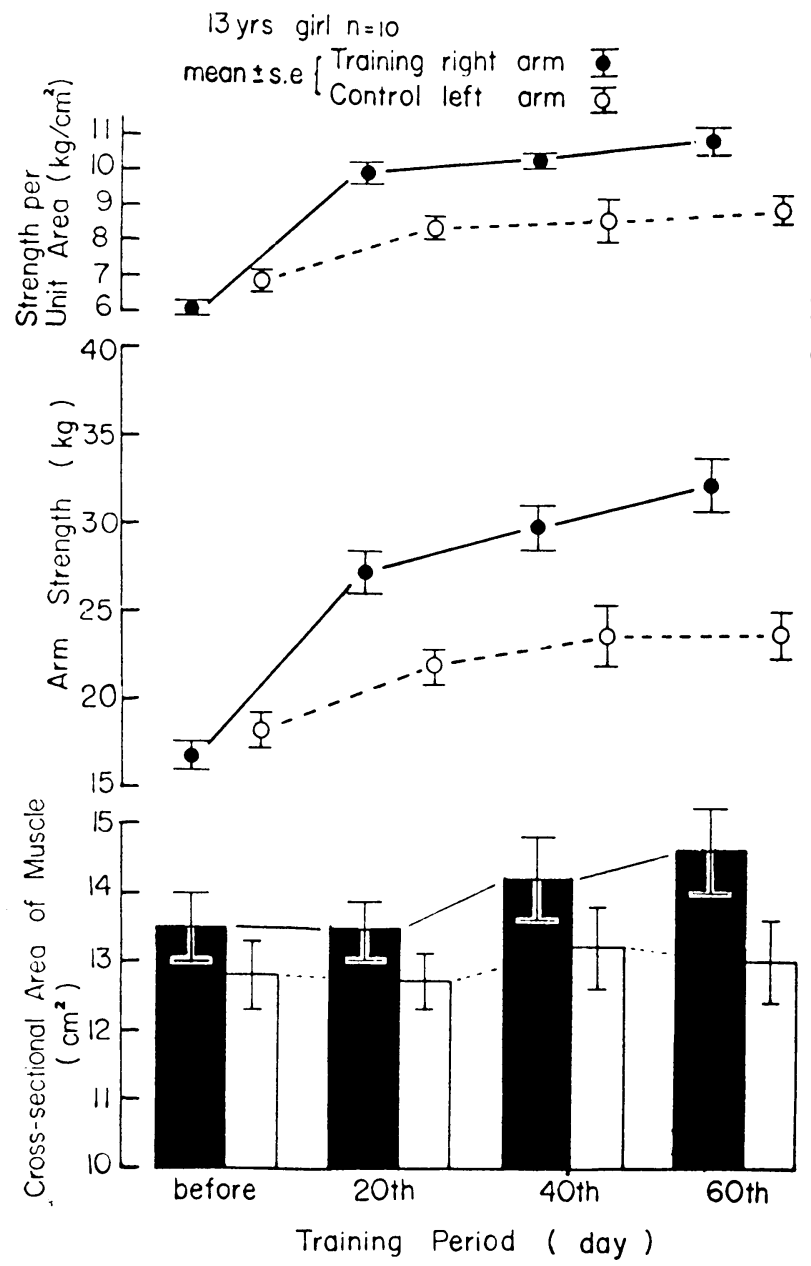

Fig. 1. Training effect by isometric contraction on strength, cross-sectional area, and strength per unit area of human arm flexor. 
The training for muscle strength conducted by Fukunaga and myself consisted of three trials of an isometric contraction by voluntary effort against the resistance with straingauge for 10 seconds with one minute intermission. A set of three trials of muscle contraction was done once a day, except Sunday extended from 6 weeks to 100 days. The training was given always on the right elbow flexor. The left arm was not trained and used for the control of the experiment. For the experiment of training, five male adults aged from 23 to 27 , ten boys aged 13 and ten girls aged 13 served as the subjects. During the training, the cross-sectional areas of the upper arm of right and left sides were measured by ultrasonic photography with regular intervals of around $\mathbf{2 0}$ days, and the strength per unit area was calculated throughout the periods. It was found that the increase of cross-sectional area was not significant at the test on day $\mathbf{2 0}$ of the training, while the increase of strength was significant at the same period. Therefore, the strength per unit cross-sectional area was increased significantly from the first stage of training. After the test of 40th day of the training, the cross-sectional area of muscle was increased progressively toward the end of training, together with increase of strength. As the result, the strength per unit cross-sectional area was increased during the training from $6.3 \mathrm{~kg} / \mathrm{cm}^{2}$ up to $10.0 \mathrm{~kg} / \mathrm{cm}^{2}$ in the average at the extended position of the arm, from $4.7 \mathrm{~kg} / \mathrm{cm}^{2}$ up to $7.5 \mathrm{~kg} / \mathrm{cm}^{2}$ at the flexed position of the arm. Among three groups of subjects of different age and sex, there was not found any fundamental difference.

From this result, it must be concluded that there are two contributing factors to improve the strength by muscle training: one is the increase of cross-sectional area of muscle, and the other is the increase of nerve discharge to the muscle. Besides these two factors of course, there must be other different contributing factors of chemical and structural nature. It can be supposed that the training effect at the first stage is due to the increase of the nerve discharge to the muscle from the brain, and the training effect from the middle stage is due to the increase of cross-sectional area of muscle, together with more efficient nervous control and increases of nervous impulses. Base on these results, we could call the training effect with increase of cross-sectional area as the increase of "physiologic limit", and the training effect on strength without change of muscle mass as the elevation of "psychologic limit". It is supposed that some discrepancies among the results and their interpretation by several authors might be solved by differentiating these two contributing factors mentioned above.

\section{Training of Muscle Power}

In every athletic performance, muscle strength should be transformed to the muscle power by combining the speed of muscle contraction. At the first step of study, $M$. Kaneko and I had introduced the measurement of muscle power mechanically by using an inertial wheel originally deviced by $A$. V. Hill in 1922, in Japanese track and field athletes. Although there was a close relationship between the power and the maximum strength of the knee extensor, there were several exceptions in skilled sprinters and jumpers who showed higher power than expected from their maximum strength. These athletes having higher power must be gifted by higher speed of muscular contraction than other fellow athletes.

In a previous experiment, K. Watanabe, M. Kaneko and $I$ have tested the training effect on power developed by elbow flexion, in which thirty high school boys were engaged for eight weeks. The subjects were classified into five groups, six in each, consisting of four training groups and one control group. The training was conducted with different loads in each group: 1) Maximum strength $\left(P_{0}\right) \times 5$ sec $\times 2$ repetitions, 2) 9/10 $P_{0} \times 5$ times of contraction, 3) 2/3 $P_{0} \times 10$ times, and 4) $1 / 3 P_{0} \times 25$ times. The number of repetitions for each group was determined to be equivalent to the Impulse (the time average of the force multiplied by the time interval which the force acts) for the maximum strength training. Before and after the training, the power was measured by the inertia wheel with the load of $30.3 \mathrm{~kg}$ in equivalent mass, and the strength was also tested. The most remarkable effect was found in the $1 / 3 P_{0}$ load group.

On the second step of study, we have tried to approach the problem by another way considering the "force-velocity curve" of muscle. For this purpose, a simple apparatus has been set up at the laboratory. When the subject flexes his elbow joint maximally, a combined isotonic lever rotates to lift the weight suspended on a gear. The maximum velocities under different loads were measured by using an electro-goniometer, devised by $P$. V. Karpovich originally, which was equipped at the axis of the isotonic lever. The relationship among force (strength), velocity (speed) and mechanical power in the average values in thirteen male and fifteen female adults was presented here. When the force is presented as the percentage of the maximum force (maximum strength), very similar relation is observed in male and female. The maximum power was calculated to be found when the force and velocity were about $35 \%$ of the maximum values in both sexes. From these results it may be supposed that the sexual difference in muscle power is mainly due to the difference of maximum strength. And as was discussed above, the sexual difference of the maximum strength may be due to the volume of the muscle.

Besides such regularity observed in male and female in the average values, there are individual variations in 

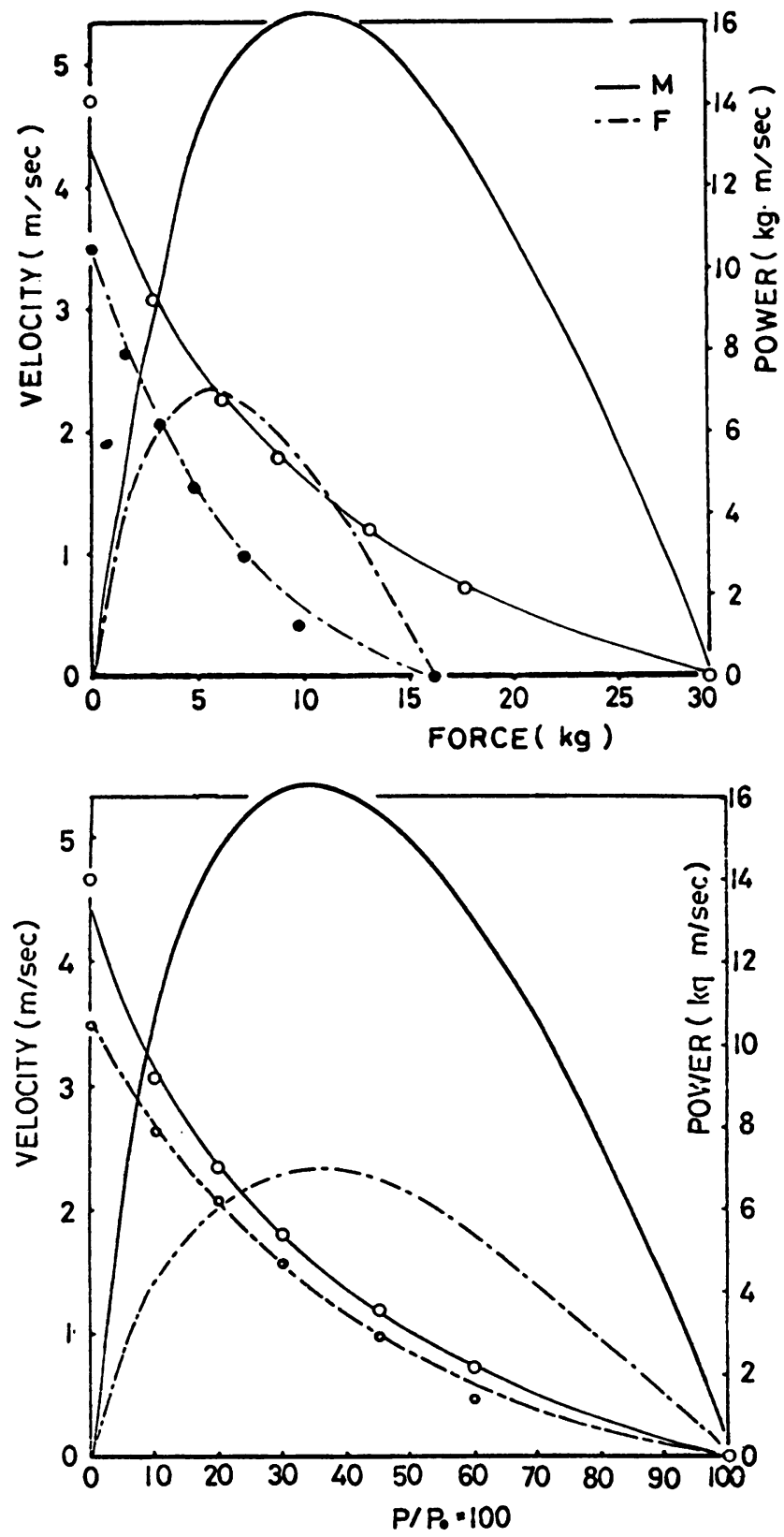

Fig. 2. Force-velocity and power relationship of human arm flexor in male and female adults.

Left: In absolute values. Right: In percentage of maximum strength.

the pattern of "force-velocity" curve which are related to the intrinsic nature of individuals and/or related to their athletic events. Based on these considerations, the power training has been conducted in twelve male adults by isotonic contraction lifting the load with special respect to see the effect on force-velocity relationship.
The load used for training was zero, thirty, sixty or hundred percent of the maximum strength. The training consisted of ten maximum voluntary contractions of elbow flexor once a day lifting the load specific to the group. The results were found as follows.

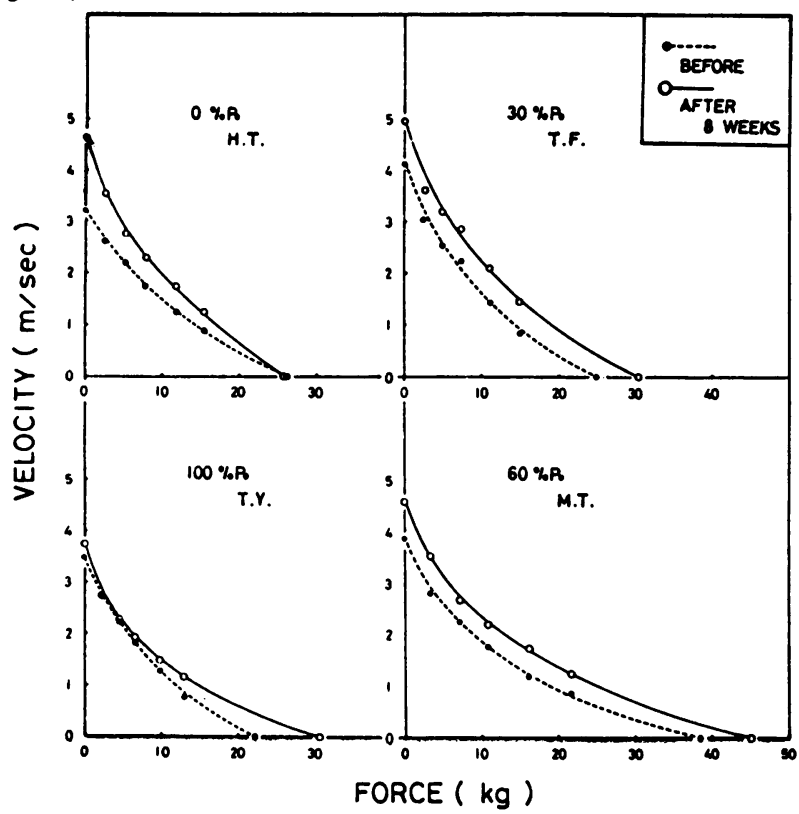

Fig. 3. Training effect by isotonic contraction with different loads on force-velocity relationship in arm flexors in male adults.

The subjects who trained with the maximum isometric contraction ( $1 \times P_{0}$ load) showed a considerable increase in strength and velocity under the larger loads. The subject who trained with maximum contraction without load $\left(0 \times P_{0}\right.$ load) showed no increase in the strength but showed a considerable increase of velocity under the smaller load. The subjects of $0.3 \times P_{0}$ and $0.6 \times P_{0}$ load groups showed all-round improvement in the force-velocity relationship.

This fact may suggest that the training with maximum strength or maximum speed is effective merely to its own direction. On the other hand, the training by dynamic contraction with adequate load could improve both the force and velocity factors, resulting the improvement of the power. Therefore, the training must be arranged specifically to the athlete according to his purpose. To improve the maximum strength, the isometric contraction with the maximum load must be adopted for basic training. To improve only the maximum speed of muscular contraction, the dynamic contraction without additional load must be enough. However, for all-round power training, it should be more recommendable to use a certain load, say from 30 to 60 percent of the maximum strength. In this sense, the strength training and the power training could not be mixed up on the same table. 
The muscle training must be prescribed for athletes, respecting the "status presence" of work capacity of individuals, and toward the "ideal pattern of force-velocity relationship" specific to each athletic event as well.

\section{REFERENCES}

1. ASMUSSEN, E: Methods for evaluation of muscle strength. Testing and Observation Inst. of the Dan. Nat. Ass. for Infantile Paralysis. Hellerup Denmark, Comm. Nr. 5, (1959).

2. HETTINGER, Th.: Isometrishes Muskeltraining. Georg Thiem Verlag, Stuttgart (1968).

3. HILL, A. V.: Maximum work and mechanical efficiency of human muscles and their most economical speed. $J$. Physiol. 56, 19-41, (1922).

4. HILL, A. V.: The heat of shortening and the dynamic constants of muscle. Proc. Roy. Soc. B. 126, 136-195, (1938).

5. IKAI, M. and A. H. STEINHAUS: Some factors modifying the expression of human strength. J. Appl. Physiol. 16 , 157-163, (1961).

6. IKAI, M. and M. KANEKO: Etude de la puissance musculaire à l'aide d'une roue à inertie. Theorie et Pratique en Culture Physique. 3 (2), 5-11, (1966).

7. IKAI, M., K. YABE and K. ISCHII: Muskelkraft und musculäre Ermüdung bei willkürlicher Anpassung und elektrischer Reizung der Muskels. Sportarzt und Sportmedizin, Heft 5, 197-204 (1967).

8. IKAI, M. and T. FUKUNAGA: Calculation of muscle strength per unit cross-sectional area of human muscle by means of ultrasonic measurement. Int. Z. angew. Physiol. 26, 26-32, (1968).

9. IKAI, M. and T. FUKUNAGA: A study on training effect on strength per unit cross-sectional area of muscle by means of ultrasonic measurement. Int. Z. angew. Physiol. 28, 173, 1970.

10. KANEKO, M. and M. IKAI: A study on muscular power with inertia wheel. Proc. Int. Congress of Sport Sciences, 1964, Tokyo, The Japanese Union of Sport Sciences, Tokyo. 430-432 (1964).

11. KARPOVICH, P. V. and P. D. GOLLNICK: Electrogoniometric study of locomotion and of some athletic movements. Fed. Proc. 21, 313 (1962).

12. WILKIE, D. R.: The relation between force and velocity in human muscle. J. Physiol. 110, 249-280, (1950). 


\title{
FORCE DEVELOPMENT BY STATIC AND DYNAMIC MUSCLE TRAINING
}

\author{
J. WARTENWEILER, M.D.
}

Abt. X fur Naturwissenschaften, Eidg. Techn. Hochschule, Zurich, Switzerland

\section{ABSTRACT}

1. Static Maximal Force

While holding his arms stretched horizontally forward, the subject had to press in an inward direction against an electronic measuring device of $15 \mathrm{~cm}$ diameter.

2. Dynamic Maximal Force

As an expression of the dynamic force the acceleration force of the horizontal inward armswing was measured.

3. Comparative Groups

1. Static training group: 19 subjects

Daily training of 6 seconds armpressing with maximal force.

2. Dynamic training group: 16 subjects

Daily training of 20 single performed inward armswings with maximal force.

3. Control group: 10 subjects

No special training.

\section{Results}

After an 18 day training period Swiss soldiers, age 20, showed the following improvement:

1. By static muscle training both the static as well as the dynamic muscle force was significantly enlarged. The static force development (15.1\%) was significantly higher than the dynamic force development (11.5\%).

2. By dynamic muscle training the dynamic as well as the static muscle force was significantly enlarged. The dynamic force development $(18.1 \%)$ was significantly higher than the static force development $(9.2 \%)$.

3. The control group did not show any significance neither in the static nor in the dynamic force development.
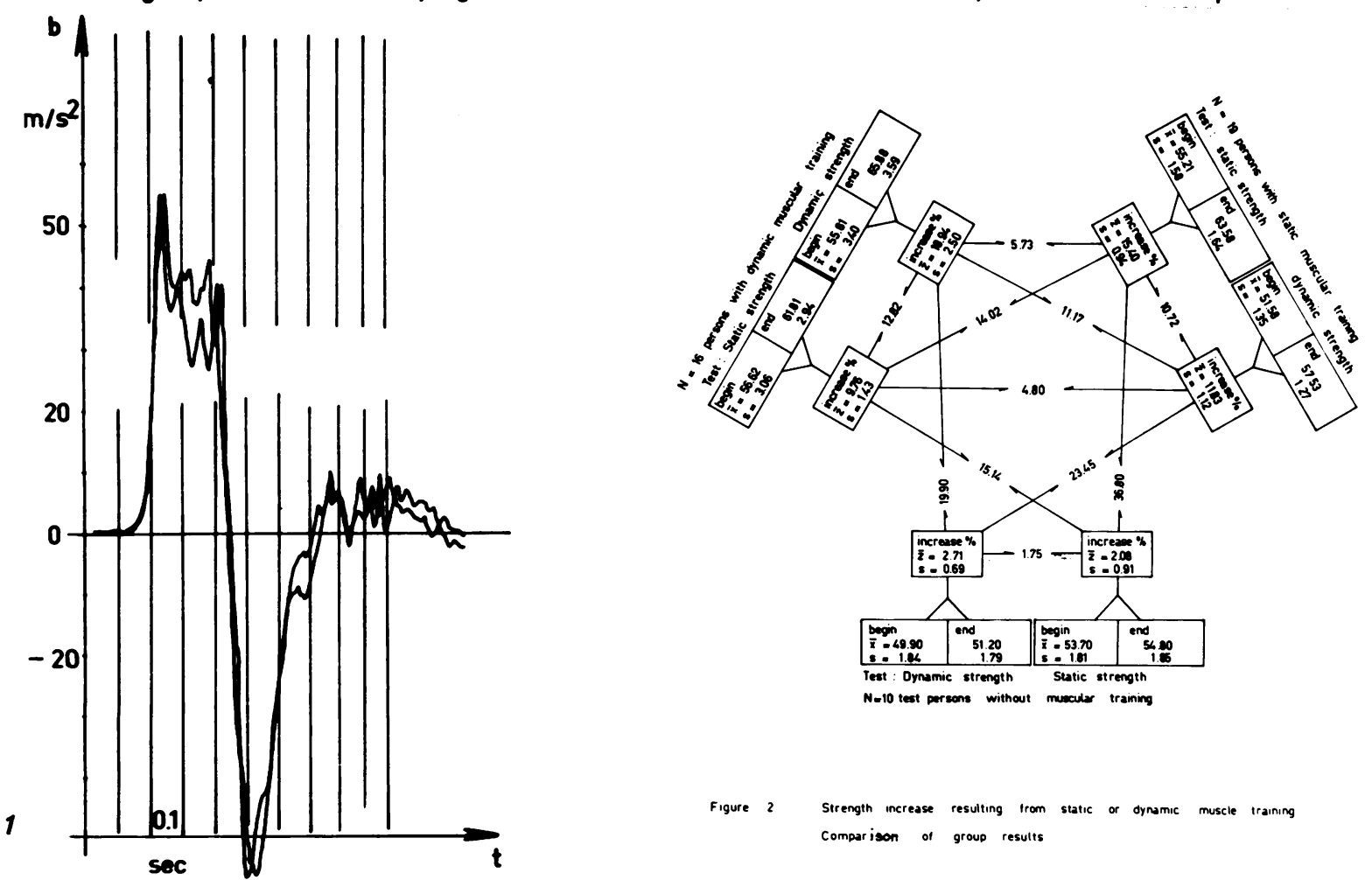

Fig. 1

Sec

$$
\text { t }
$$$$
\text { Comparison of group results }
$$ 


\title{
EXERCISE INDUCED ACTIVATION AND PERCEPTUAL MOTOR SKILL
}

\author{
B. GUTIN, Ph.D. \\ Teachers College, Columbia University, New York 10027
}

\begin{abstract}
This paper presents a theory concerning the effect of prior and concomitant physical exercise on various types of motor skills. The level of metabolic activity in the tissues, as caused by exercise, is termed the level of exercise-induced activation (E|A).
\end{abstract}

The relation between EIA and skill performance ordinarily takes the form of an inverted $U$ shaped curve. That is, as EIA level increases, performance improves up to an optimal point. Further increases in EIA cause progressive deterioration of performance.

The optimal EIA level is not the same for all tasks. Rather, it varies with the degree of inhibition required in the task. Tasks requiring a great deal of inhibition (e.g. static balance or steadiness) are performed best at a relatively low EIA level while tasks requiring little or no inhibition (e.g. arm speed) are performed best at a relatively high EIA level).

This paper summarises some research supporting such a theoretical formulation and describes some research in progress which will test deductions from this theory directly.

\section{Introduction}

It is apparent that physical exercise has a great effect on many of the organs and systems of the body. For example, we have all experienced the increased force and rate of the heart beat and the increased ventilation which accompanies vigorous activity. Of course, those of us who are not as fit as we might be experience these sensations even when the exercise is not very vigorous. Needless to say, these conscious effects of exertion are accompanied by many more profound organic changes, many of which have been identified by exercise physiologists (e.g. changes in blood pressures, temperature, blood chemistry, etc.).

Persons interested in athletic performance have tried to determine the effects of prior exercise on subsequent performance of many athletic events. This will be recognized as "warm-up" research or "fatigue" research, depending on whether the effects are positive or negative.

An area which has not been investigated extensively until quite recently is the effect of such exertion on the performance and learning of perceptual-motor and intellective tasks. A clarification of such effects should be of help to people involved in a wide variety of fields in which optimal performance of such tasks is desirable. Certainly, many sports require skilled performance during or immediately after strenuous exertion.

The purpose of this paper is to outline a theoretical framework which may help to explain the relationship between physical exertion and a wide variety of motor tasks. Then some research which tends to support this theoretical position will be discussed and several studies presently under way, which will provide more explicit tests of the deduced consequences of this theory, will be outlined. Finally, some implications of the theory for practice and for further research will be suggested.

Elizabeth Duffy (1962) has coined the term "level of activation" to describe the degree of metabolic activity in the tissues of the organism at any moment. The level of activation varies from that found in deep sleep to that found in strenuous activity. Although activation level can obviously be affected by muscular exercise it can also be affected by drugs, hormones, and emotional factors such as threat or excitement. We have all experienced the muscle tension, perspiration and increased cardiac function which often occur in emotionally charged situations. Duffy has pointed out that the relationship between activation and performance usually takes the form of an inverted " $U$ ". That is, as activation level increases, performance increases up to an optimal point and then deteriorates with further increases in activation. However, the level of activation which is optimal for one task may not be optimal for other tasks. It may be possible to clarify this complicating factor by reference to the Yerkes-Dodson (Eysenck, 1963) Law which relates motivation and task difficulty. This law posits that an intermediate amount of motivation, or drive, results in highest performance. However, the optimal amount of drive is higher for easy tasks than it is for difficult tasks. That is, difficult tasks are accomplished better in a relatively low drive state while easy tasks are performed better in a relatively high state. Since there is some similarity between the 
operational definitions of the constructs activation and motivation (i.e. they both refer to a condition characterized by muscular tension) it may be fruitful to utilize an adaptation of the Yerkes-Dodson framework to explain the effects of activation on performance of tasks of varying complexity.

As mentioned earlier, activation level is influenced by various stimuli other than exercise. However, in this review, only the effects of exercise-induced activation (hereafter referred to as EIA) will be discussed. In addition, the focus will be narrowed further to include only the effects of exercise which involves large muscle activity capable of raising the general activation level of the organism greatly as opposed to more local kinds of exercise. The last limitation is that studies using criterion tasks which are based largely on strength or endurance will not be reviewed. The main reason for the focus on EIA is that some psychologists have studied activation induced by means other than exercise and, to some extent, small muscle exercise. However, very little research has been done within this theoretical framework on large muscle EIA. In fact, in only one of the studies found which are relevant to this theory has the experimenter discussed his findings in terms of activation theory (Sjoberg, 1968). Since in large muscle activity the relationship between heart rate and oxygen consumption (metabolic activity) is linear, (Åstrand and Rodahl, 1970, p. 166) reference will often be made to heart rate as an indicant of EIA.

It was suggested earlier that it might be useful to use the Yerkes-Dodson framework to explain the variance in optimal level of EIA for different kinds of tasks. But rather than classifying tasks easy or difficult it might be more fruitful to think in terms of the degree of inhibition required in the task. For example, a static balance task requires a great deal of inhibition of movement so that the adjustments required to remain in a state of equilibrium are minor. On the other hand tasks requiring speed, in which the subject does not need to modify his movements (i.e. inhibit one movement in favour of another) in response to external stimuli, are very low in the degree of inhibition demanded. This spectrum of relative inhibition should become clearer as we consider the findings of some specific studies.

Most of the studies reviewed here did not test the inverted " $U$ " hypothesis. Rather a condition of relatively high EIA was ordinarily compared with a resting, or low EIA condition. Studies which have examined the effect of high EIA on tasks requiring little movement, such as steadiness and balance, have generally found a decrement in performance. For example, Ross, Hussman and Andrews (1954) found that strenuous exertion caused an increase in tremor and body sway. Phillips (1962) found that a ten minute period of step-ups caused a decrement of 38 percent in stabilometer performance in which a maximum of movement was required for successful performance. Although these studies indicate that reasonably strenuous exertion is harmful relative to no prior exertion, no light has been shed on the effect of moderate levels of EIA as compared to both low and high EIA. Therefore, we are presently planning studies to test the effect of various levels of EIA on hand steadiness and dynamic balance. The studies will involve either resting or riding a bicycle ergometer at a wide range of heart rates for several minutes followed by a test of hand steadiness and trials on a stabilometer which requires the subject to alter and then maintain a balanced position in response to changing environmental cues. While we expect to find that the relationship between $E I A$ and dynamic balance will take the inverted "U" form, we expect the optimal level of EIA to be relatively low on the activation continuum. Since the steadiness test requires a great deal of inhibition, we expect the optimal level of EIA for this task to be very low.

While it might be expected that the optimal level of EIA for tasks requiring little or no movement is relatively low, the opposite seems to be the case for tasks requiring speed of movement. For example, Phillips (1963) found that a ten minute step-up task which resulted in a definite drop-off in step-up performance indicating leg fatigue, and which hindered balance performance considerably, facilitated arm speed. And Ross, et al, (1954) found tapping speed to be improved following strenuous exercise. Again, it can be seen that the entire range of EIA levels was not sampled in these studies. Therefore, we are planning a study in which subjects will be tested for arm speed during and immediately after a bicycle ergometer ride at various heart rates. In light of the findings by Phillips that high EIA helped performance when compared to a rest condition, and because this type of task requires very little inhibition, we are hypothesizing that an inverted " $U$ " form may not be found, but, rather, that a linear relationship will exist between EIA and arm speed with best performance found at the highest level of EIA.

While the studies which have compared the effects of high EIA and a rest condition on tasks at opposite ends of the inhibition continuum have resulted in rather clear-cut findings (i.e. high EIA facilitates tasks demanding little inhibition and hurts performance of tasks requiring inhibition), studies which have utilised tasks more toward the middle of the inhibition continuum have not resulted in such clear-cut findings.

Schmidt (1969) investigated the effect of pedalling a bicycle ergometer at workloads of 750 and 1,200 $\mathrm{kgm} / \mathrm{minute}$ before each trial of a ladder climbing task. These workloads probably resulted in moderately high and very high EIA. The task required the subject to 
climb a free standing ladder until toppling and then to start again at the bottom rung. The number of rungs completed in $\mathbf{3 0}$ seconds was the subject's score. It was found that relative to a resting condition both workloads impaired performance, with the heavier workload having the greater effect. Caplan (1969) also found that performance of this ladder climbing task was hindered by high EIA. His exercise task consisted of ten minutes of stool stepping at a very fast rate. Thus, performance on this ladder climbing task which involves some degree of balance and some degree of fast movement, seems to be harmed by high EIA. However, there is a factor involved in the scoring of this task which makes the findings difficult to interpret. By counting the total number of rungs climbed in a test period, the total score is influenced both by the skill of the subject in climbing and balancing and by his willingness to move quickly after toppling to start his next attempt. The physiological effort involved in working continuously throughout the test period is probably limited by the rather direct transfer of fatigue from an endurance task (step-ups or cycling). Thus it is impossible to tell whether the high EIA was affecting the skill involved in the task or the physiological endurance involved in the task. In fact, when Schmidt scored his subjects by the number of rungs completed per attempt, which is a more pure measure of skill, he was unable to establish that the EIA had a significant effect on performance.

Several studies which sought to investigate the effects of what the authors called "fatigue" found that performance of the criterion tasks was facilitated. For example, Benson (1968) had his subjects ride a bicycle ergometer for two minutes at a heart rate of 180 b.p.m. before performing a three minute, three ball juggling task. The subjects repeated this procedure for a total of eleven sessions. It was found that the subjects who practiced in a so-called fatigued state performed better than the controls. Lybrand, Andrews and Ross (1954) walked subjects on a treadmill for five miles at 120 steps per minute carrying $\mathbf{4 0} \mathrm{lb}$. packs immediately prior to being tested on a manipulative problem solving task. Again it was found that the fatigued subjects performed better than the controls. Interestingly enough, the authors concluded that the exercise was not severe enough to cause a decrement in performance but rather served to "warm-up" the subjects. They suggested that a more severe work task would have resulted in poorer performance on the criterion task. Therefore, they seemed to be saying that an inverted " $U$ " relationship might exist between EIA and manipulative problem solving performance.

By virtue of the fact that the juggling and manipulative problem solving tasks used by Benson and Lybrand et al, were facilitated by relatively high EIA, it may be tentatively concluded that they require relatively little inhibition for optimal performance. Of course, before being able to draw any definitive conclusions about the relationship between EIA and performance on these kinds of tasks, it will be necessary to sample various levels of EIA in a systematic way rather than merely comparing a rest condition to a fatigue condition.

Kendrick (1967) reported a study in which subjects performed a dual choice response time task immediately before and after a five minute bout of strenuous step-ups. The task involved reacting to a sound and sight stimulus by moving in one of two directions. Both reaction time (RT) and movement time were included in the measure. The scores immediately after the step-ups, at which time the subjects were clearly at a high EIA level, were significantly worse than before the step-ups. The scores after a five minute recovery period, at which time the EIA level of the subjects was probably slightly elevated above rest, were better than before the exercise bout. Kendrick interpreted this finding to mean that the subjects showed learning on the task, since it was relatively unfamiliar to them. But it is also possible to interpret this enhanced performance as due to a slightly elevated EIA level.

Several studies which investigated the relative effect of rest and very strenuous exertion on skilled tasks found that performance was not significantly different under these two conditions. Meyers, et al (1969) used a bench stepping task followed by simple RT trials. Gutin (1968) had his subjects run on a treadmill at seven m.p.h. at a grade that was seven degrees at the beginning of the run and increased by one degree each minute. The subjects ran to a subjective state of exhaustion and immediately performed on a pursuit rotor or stylus maze. Kendrick (1967) had his subjects perform basketball free throws and basketball jump shots after five minutes of very strenuous step-ups. Welch (1969) interpolated very strenuous bouts of stool stepping between trials on a pursuit rotor. One explanation of these null results is that the comparisons were made between very high and relatively low EIA levels on tasks where the optimal level is toward the centre of the activation continuum.

One study which did vary EIA in a systematic way was reported by Babin (1966). His subjects pedalled a bicycle ergometer with either the arms or legs for three, four, five, six or seven minutes. The workload for the arms was $4,925 \mathrm{ft}$. Ibs./minute and the workload for the legs was $8,280 \mathrm{ft}$. Ibs/minute. Before and after the arm or leg work the subjects performed ten simple RT trials. Since Babin was operating under a local fatigue rather than general activation framework, he had the subjects take the RT tests with the right hand before and after the arm work and with the right leg before and after the leg work. For both arms and legs the results took the inverted " $U$ " form with post-exercise RT being faster 
than pre-exercise RT after the three, four and five minute workloads, similar to pre-exercise RT after the six minute workloads and significantly worse than pre-exercise RT following the seven minute workload. Although Babin did not statistically compare RT across work periods, the fastest RT means followed the four minute work periods for both arms and legs.

Another study which utilized several EIA levels was conducted by Sjoberg (1968). An important difference between this study and all the others reviewed so far is that the criterion task, dual choice RT trials, was performed by the subjects while working on a bicycle ergometer instead of immediately afterward. Subjects worked at loads of 150, 300, 450, 600, and 750 $\mathrm{kgm} / \mathrm{minute}$ for $5 \frac{1}{2}$ minutes and then performed the RT trials while continuing to pedal. These workloads resulted in mean heart rates of 84 b.p.m. at rest to 147 b.p.m at the highest work load. Therefore, the EIA levels ranged from relatively low to moderately high. The results took a clear-cut inverted " $U$ " form with best performance occurring at the $450 \mathrm{kgm} / \mathrm{minute}$ workload. The mean heart rate at this workload was 121 b.p.m. The design of the study did not permit an adequate comparison of the performance at rest with that during the various workloads.

In order to extend these findings by Babin and Sjoberg we are planning a study in which subjects will walk on a treadmill at heart rates ranging from about $\mathbf{8 0}$ (standing still) to 180 b.p.m. This procedure will allow us to adjust the workload to the subject since the more fit person ordinarily develops a lower heart rate than an unfit person for the same workload. After several minutes of walking at the specified heart rate the subject will perform a number of simple RT, dual choice RT and 5 choice RT trials. These three tasks would seem to vary in the amount of inhibition they demand for efficient performance. In a simple RT task the subject only has to inhibit his movement until the stimulus light goes on. In dual choice RT the subject has to inhibit his movement until he decides in which of two directions to move. And in a five choice RT task he has to inhibit his movement until he processes even more information than in the dual choice task. Put another way, in simple RT only temporal inhibition is required whereas in choice RT both temporal and spatial inhibitions are necessary. We are expecting simple RT performance to be optimal at a relatively high level of EIA, perhaps 160 b.p.m. Dual choice RT performance should be optimal at an intermediate EIA level, perhaps 120 b.p.m. And a relatively low level of EIA, perhaps 100 b.p.m., should be optimal for five choice RT.
At this point it may be desirable to summarize the theoretical formulation under which the effects of prior and concomitant exercise on perceptual-motor skill may be interpreted. First, it is clear that exercise raises the level of metabolic activity in the organism, which is defined as exercise-induced activation. Furthermore, it is clear that elevation of EIA can affect performance of motor skills. The general hypothesis presented here is that the relationship between EIA and skilled performance will ordinarily assume an inverted " $U$ " form with optimal performance obtaining at an intermediate level of EIA.

In order to explain the fact that different tasks seem to have different optimal EIA levels, it is further theorized that tasks can be arranged along a continuum based on the degree of inhibition necessary for optimal performance. Tasks requiring little inhibition (e.g. speed of movement) would be performed optimally at a high EIA level, whereas tasks requiring a great deal of inhibition (e.g. hard steadiness) would be performed best at very low levels of EIA. And tasks involving intermediate levels of inhibition would be performed best at intermediate EIA levels.

As we continue to test the deduced consequences of this theory, its explanatory value will become clearer. If we could assume for a moment that the theory will be found to have great explanatory value (i.e. the specific hypotheses deduced from the theory are confirmed), the implications for optimal skill performance are considerable. For example, sports skills could be analysed for the degree of temporal and spatial inhibition involved and appropriate warm-up activities could be undertaken to assure optimal performance. The performance of a wide variety of speaking, writing, locomotive, and industrial skills may be enhanced by appropriate manipulation of EIA level. Another important implication of this theory is that subjects who practice a novel skill under optimal or less than optimal EIA conditions may exhibit long range positive or negative effects in situations where EIA level is not manipulated. For example, Benson (1968) found that even when tested without prior exercise the subjects who had practiced in a state of high EIA performed better than the controls. In other words, both performance and learning of the juggling task were enhanced by elevated EIA. Research which can shed more light on this question is certainly needed.

It is also desirable to determine whether the explanatory power of this theory extends to tasks requiring strength and power as well as to tasks of a more verbal, numerical or symbolic nature. 


\section{REFERENCES}

1. ÅSTRAND, Per-Olaf, and RODAHL, Kaare. Textbook of work physiology. New York: McGraw-Hill, 1970.

2. BABIN, W. L. The effect of various work loads on simple reaction latency as related to selected physical parameters. Unpublished Doctoral Dissertation, University of Southern Mississippi, 1966.

3. BENSON, D. W. Influence of imposed fatigue on learning a jumping task and a juggiing task. Research Quarterly, $1968,39,251-259$.

4. CAPLAN, C. S. The influence of physical fatigue on massed vs. distributed motor learning. Unpublished Doctoral Dissertation, University of California, Berkeley, 1969.

5. DUFFY, Elizabeth. Activation and behaviour. New York: John Wiley and Sons, 1962.

6. EYSENCK, H. J. The measurement of motivation. Scientific American, 1963, 208, 130-140.

7. GUTIN, Bernard. Effect of systemic exertion on rotary pursuit and maze performance and learning. Paper presented at Second International Congress of Sport Psychology, Washington, D.C., November 1, 1968.

8. KENDRICK, L. Performance in selected gross motor skills before and after fatiguing exercise. Unpublished Doctoral Dissertation, Louisiana State University, 1967.

9. LYBRAND, W. A., ANDREW, T. G. and ROSS, S. Systemic fatigue and perceptual organization. American Journal of Psychology, 1954, 67, 704-707.

10. MEYERS, Carlton R., ZIMMERLI, William, FARR, S. David and BASCHNAGEL, Norbert A. Effect of strenuous physical activity upon reaction time. Research Quarterly, 1969, 40, No. 2, 333-337.

11. PHILLIPS, W. H. The effects of physical fatigue on two motor learning tasks. Unpublished Doctoral Dissertation, University of California, Berkeley, 1962.

12. PHILLIPS, W. H. Influence of fatiguing warm-up exercises on speed of movement and reaction latency. Research Quarterly, 1963, 34, 370-379.

13. ROSS, S., HUSSMAN, T. A. and ANDREW, T. G. Effects of fatigue and visual functions. Journal of Applied Psychology, 1954, 38, 119-125.

14. SCHMIDT, R. Performance and learning a gross muscular skill under conditions of artificially induced fatigue. Research Quarterly, 1969, 40, 185-191.

15. SJOBERG, H. Relations between different arousal levels induced by graded physical work and psychological efficiency. Report from the Psychological Laboratories, No. 251, University of Stockholm, Sweden, April, 1968.

16. WELCH, M. Specificity of heavy work fatigue: Absence of heavy leg work to coordination tasks using the arms. Research Quarterly, 1969, 40, 402-406. 


\title{
AEROBIC CAPACITY AND MUSCLE FACTOR AS PHYSIOLOGICAL PARAMETERS OF PHYSICAL WORK CAPACITY
}

\author{
I. ILIEV, M.D. and R. KOSSEV, M.D. \\ Higher Institute of Physical Culture, Sports Physiology Section, Sofia, Bulgaria
}

Investigations on aerobic work capacity have in the last two decades been largely adopted in sports medicine. Data published by Åstrand, Saltin, Taylor, Wyndham, Borissov, Farfel, Horak and others gave a basis for evaluation of this parameter in various sports. In the course of our studies on aerobic capacity in a number of sports we obtained practical evidence of the high degree of correlation between aerobic capacity and specific working capacity in sportsmen.

Our results showed, at the same time, that other factors besides aerobic capacity are of importance for the ergometric working capacity and, probably, for the specific one. In this respect the state of the muscles as a morphological and functional unit of motor activity can be considered.

The interrelationship between ergometric work capacity, aerobic capacity and a criterion for the functional state of the muscles has been studied, the last being tested with electric stimulation before and after a maximal ergometer exercise. 400 outstanding sportsmen was tested in the Laboratory and the results analysed.

Because of their dependence on body weight, relative values have been used everywhere in place of raw scores; for aerobic capacity - $\dot{V} 0_{2} / \mathrm{kg}$, for ergometric working capacity $-\mathrm{W} / \mathrm{kg}$, where $\mathrm{W}$ represents work power at $\mathrm{VO}_{2}$ max. The criterion for the functional state of the neuro-muscular apparatus does not depend on body weight and is evaluated according to a ten degree scale.

These "M.F." values originate from the data on the lability of the neuromuscular apparatus, studied by a series of stimulations lasting $1000 \mathrm{msec}$ and with a frequency of the stimuli of $20 \mathrm{~Hz}, 40 \mathrm{~Hz}, 60 \mathrm{~Hz}, 80 \mathrm{~Hz}$ etc. The lability is tested after two parameters: optional rhythm per sec. and maximal rhythm per sec. Stimulation is advised by an electronic stimulator with a capacity for reproduction of high frequency serial impulses, whereas biopotentials are recorded on a sensitive electromyograph. The values of the optimal and maximal rhythm before and after an ergometric work combine in a final evaluation, which shows the effect of the work done upon the state of the neuromuscular apparatus.

The main results of the analysis are given in Table I

The aerobic capacity as well as the criterion for the functional state of the neuro-muscular apparatus (the muscle factor - MF) taken separately display a high degree of correlation with ergometer working capacity $(r$ $=0.91$ resp. 0.76). This demonstrated the importance of the MF for a prolonged working capacity. It appears that this factor, together with aerobic capacity, has a limiting effect on maximal working capacity. The multiple correlation of aerobic capacity and MF with maximal working capacity is found to be extremely high ( $r=$ 0.97) which allows to be concluded that these two factors are complementary and compensating to each other as far as ergometric achievements are concerned. This is corroborated by the partial correlation coefficients. At constant values of the aerobic capacity, muscle factor correlates with ergometer working capacity at a correlation coefficient $r=0.82$. At constant values of MF the corresponding partial correlation coefficient for the aerobic capacity is 0.93 .

\footnotetext{
All kinds of sports

Rowing

Wrestling

Boxing

$M$. pentathlon

Light athletic

Water polo
}

Table I

$\begin{array}{llllll}0_{2} / \mathrm{kg} & \mathrm{MF} & 0_{2} / \mathrm{kg} & \begin{array}{l}0_{2} / \mathrm{kg} \\ \text { and } \\ \mathrm{MF}\end{array} & \begin{array}{l}\text { By MF } \\ \text { const. }\end{array} & \begin{array}{l}\text { By } 0_{2} \\ \text { const. }\end{array} \\ 0.91 & \mathrm{~W} / \mathrm{kg} & \mathrm{MF} & 0.97 & 0.93 & \\ 0.84 & 0.76 & 0.51 & 0.97 & 0.83 & 0.82 \\ 0.85 & 0.67 & 0.43 & 0.91 & 0.74 & 0.62 \\ 0.72 & 0.79 & 0.64 & 0.98 & 0.92 & 0.94 \\ 0.90 & 0.80 & 0.22 & 0.87 & 0.96 & 0.47 \\ 0.80 & 0.33 & 0.14 & 0.90 & 0.75 & 0.67 \\ 0.89 & 0.75 & 0.50 & 0.91 & 0.81 & 0.32\end{array}$


Table II

\begin{tabular}{|c|c|c|c|c|c|c|c|}
\hline & $\begin{array}{l}0_{2} / \mathrm{kg} \\
W_{/ k g}\end{array}$ & $\begin{array}{l}M F \\
W / \text { kg }\end{array}$ & $\begin{array}{l}\text { Ind. of pul } \\
\text { mon. vent. } \\
\text { W/kg }\end{array}$ & $\begin{array}{l}\text { Max. heart } \\
\text { rate } \\
W / \text { kg }\end{array}$ & $\begin{array}{l}\text { Heart rate } \\
\text { by } 210 \text { and } \\
240 \mathrm{~W} \\
\mathrm{~W} / \mathrm{kg}\end{array}$ & $\begin{array}{l}\text { Hypoxic } \\
\text { resistance } \\
\mathrm{W} / \mathrm{kg}\end{array}$ & $\begin{array}{l}\text { Blood } \\
\text { flow } \\
\text { velocity } \\
W / k g\end{array}$ \\
\hline All kinds of sports & 0.91 & 0.76 & -0.38 & 0.38 & -0.33 & 0.04 & 0.19 \\
\hline Rowing & 0.84 & 0.67 & - 0.33 & 0.42 & -0.30 & 0.01 & 0.15 \\
\hline Wrestling & 0.85 & 0.79 & -0.31 & 0.21 & -0.12 & -0.08 & 0.04 \\
\hline Boxing & 0.72 & 0.80 & -0.40 & 0.20 & -0.13 & -0.09 & -0.18 \\
\hline M. Pentathlon & 0.90 & 0.33 & -0.37 & 0.12 & -0.40 & -0.19 & 0.05 \\
\hline Light athletic & 0.80 & 0.75 & -0.43 & 0.22 & -0.36 & 0.23 & 0.21 \\
\hline Water polo & 0.89 & 0.67 & -0.33 & 0.37 & -0.22 & -0.21 & 0.43 \\
\hline
\end{tabular}

The indpendent role of these two factors (aerobic capacity and MF) is indicated by relatively low coefficient of the correlation between them (0.51). If analysing the data for a single subject this specific interrelation can be still more pronounced.

The interrelation between aerobic capacity and MF are specific for each kind of sport, demonstrated by data analysis for the different sports investigated. In boxers the correlation between MF and ergometric working capacity is higher $(r=0.83)$ than between aerobic capacity and ergometric working capacity $(r=0.72)$ and the correlation coefficient between aerobic capacity and MF extremely low $(r=0.22)$. The complementary significance of the two factors in boxers is demonstrated by the exceptionally high coefficient of multiple correlation $(r=0.98)$.

Encouraged by these results we tried to involve in our analysis some other factors, which might eventually be of some importance when determining the maximal working capacity in sportsmen. We took for the purpose some of the physiological parameters commonly used in complex functional investigations. Pulmonary

ventilation, heart rate, hypoxic resistance, blood flow velocity, gave a correlation coefficient with the ergometric working capacity that was found to be rather low (from 0.04 to 0.38 ) (Table II).

The most surprising fact which casts doubt on the use of data of aerobic capacity obtained indirectly through nomograms existing nowadays for functional assessment is the lack of essential correlation between heart rate at submaximal levels of ergometer load and the working capacity.

In conclusion it may be pointed out that the maximalce working capacity is limited by at least two groups of $\rightleftharpoons$ physiological factors - the system of oxygen supply represented mostly by the aerobic capacity, on the one hand, and MF - from the other, While the aerobic capacity is generally acknowledged and is widely used as a criterion fro physical working capacity, the MF is commonly neglected and in this respect not yet sufficiently studied. If tested it may often complete the evaluations based on aerobic capacity data and explain some lack of correspondence and discrepancies between medical assessment and practical achievements in sport. 


\title{
THE EFFECT OF TRAINING WITH EQUAL PHYSICAL POWER BUT DIFFERENT WORK IN IDENTICAL TWINS
}

\author{
W. MELLER, H. MELLEROWICZ2, L. ROCKER ${ }^{3}$ and H. STOBOY
}

(1 \& 2) 1 Berlin 33, Forckenbeckstr. 20, Germany

(3) 1 Berlin 33, Thielallee 88/92

(4) 1 Berlin 33, Clayallee 229/233

\begin{abstract}
Identical twins were exercised with barbell-weights in bench-pressing and knee-bending for six weeks. The one had to perform the exercises with a small number of repetitions and heavy weight (heavy work), the other with a large number of repetitions and small weight (light work). For both exercises the increase of strength by training with heavy work was $15 \%$ more than by training with light work. Also the height of a jump started with bent knees was more increased after training with heavy work. The time needed for pushing the barbell-weights upward during bench-pressing was shortened with heavy work training by $11.3 \%$, increased however with light work training by $18.7 \%$. During fast knee-bending with barbell-weights a similar result was achieved. The different result of training is explained by the measurement of strength, static endurance, strength endurance and electrical activity of the quadriceps femoris.

The percentage of strength increasing was distinctly higher after training with heavy work than after training with light work. While the static endurance increased after training with heavy work it decreased after training with light work by $57 \%$. Therefore, the strength-endurance shows a considerable increase after training with heavy work, while this value is decreased after training with light work. The integrated electrical activity was diminished after training with heavy work by about $40 \%$, that is due to an economisation of the muscle contraction by diminishing the number of simultaneously contracting motor units. After training with light work the electrical activity did not change to any practical extent.
\end{abstract}

